This is an electronic reprint of the original article. This reprint may differ from the original in pagination and typographic detail.

Author(s): Shaikh, Aijaz A.; Karjaluoto, Heikki; Chinje, Nathalie Beatrice

Title: $\quad$ Consumers' perceptions of mobile banking continuous usage in Finland and South Africa

Year: $\quad 2015$

Version:

Please cite the original version:

Shaikh, A. A., Karjaluoto, H., \& Chinje, N. B. (2015). Consumers' perceptions of mobile banking continuous usage in Finland and South Africa. International Journal of Electronic Finance, 8(2-4), 149-168. https://doi.org/10.1504/IJEF.2015.070528

All material supplied via JYX is protected by copyright and other intellectual property rights, and duplication or sale of all or part of any of the repository collections is not permitted, except that material may be duplicated by you for your research use or educational purposes in electronic or print form. You must obtain permission for any other use. Electronic or print copies may not be offered, whether for sale or otherwise to anyone who is not an authorised user. 


\title{
Consumers' perceptions of mobile banking continuous usage in Finland and South Africa
}

\begin{abstract}
:
This study examines continuous usage behaviour related to mobile banking (m-banking) among consumers living in Finland (FI) and South Africa (ZA). The study investigates three postadoption behavioural consequences - namely, trust, satisfaction, and word of mouth. Using purposeful sampling techniques, we found that trust plays a significant role in promoting continuous usage of m-banking. In general, the respondents reported high levels of trust in mbanking technology and were satisfied with the m-banking application and services. In addition, convenience, user friendliness, and speed emerged as the main sub-topics related to satisfaction. In most cases, the convenience of using m-banking dominated the recommendation criteria. However, users, especially those in ZA, generally do not promote m-banking services to others. This study shows that for the majority of users, m-banking usage is related to increased satisfaction with the bank, implying that m-banking services should be a vital part of banks' strategy to retain customers.
\end{abstract}

Keywords: mature market, emerging market, mobile banking, m-banking, trust, satisfaction, word of mouth, Finland, South Africa, e-finance, electronic finance.

\section{Introduction}


In the past two decades, banks and microfinance institutions have developed different mobile banking (m-banking) models and deployed them successfully through mobile network operators in several developed, emerging, and developing countries. Among these countries, Kenya was first to introduce a text-based m-banking service called 'M-Pesa'. The Safaricom (Kenya's major mobile operator) launched the M-Pesa mobile money service in Kenya in March 2007 (Cisco, 2013). M-Pesa has quickly grown to become the most successful mobile money service in the world. By June 2013, M-Pesa had more than 15 million customers compared with 14.9 million in June 2012. In addition to M-Pesa, McKinsey \& Co. (2014) reports that other m-banking-related deployments have reached a sustainable scale and achieved operational profitability: some notable examples include Easypaisa in Pakistan, MTN in Uganda, Vodacom in Tanzania, FNB in South Africa, and GCASH and Smart Money in the Philippines.

M-banking serves mainly to expand the consumer base, improve operations, reduce costs, and generate an additional source of revenue for financial institutions. M-banking services are accessed through portable devices such as cell phones, smartphones, and tablets for conducting financial (e.g., funds transfer) and non-financial transactions (e.g., balance enquiry) (Shaikh and Karjaluoto, 2015). Both banked and under-banked consumers can use m-banking to transfer money, make purchases, and even pay utility bills using a portable device. As a result, mbanking has expanded the outreach of financial services, which had previously been concentrated in urban centers, and has allowed the previously under- or un-banked population to access affordable and 'anytime, anywhere' banking services. This impact is less pronounced in developed economies but still profound (Ensor et al., 2012). 
Research has identified m-banking as an e-banking channel (e.g., Adesina and Ayo, 2010), an important information system (e.g., Luo et al., 2010), an extension of e-payment systems (e.g., Schierz et al., 2010), and a sub-set of e-finance (e.g., Ratten, 2012). Figure 1 provides a detailed overview of payment systems and illustrates the two types of payment systems: retail and wholesale. Wholesale payments are managed and settled through an innovative and specialised funds transfer system called Real Time Gross Settlement Systems. Retail payments are standard banking transactions that can be conducted through paper instruments (e.g., checks) or electronic channels, products, and services (e.g., automated teller machines, point-of-sale terminals, Internet, mobile, debit cards, credit cards). E-payment transactions can be further divided into emoney and e-finance and transactions. E-money transactions do not necessarily require a consumer to have a bank account, and these types of transactions are mostly prevalent in developed countries. Conversely, an e-finance transaction is an e-banking transaction usually conducted by bank customers using different e-channels anytime and anywhere. Policy makers, regulators, researchers, and practitioners have all recognised the importance of m-banking in making financial transactions more convenient and as an effective method for taking banking services to the masses, especially the un-banked population. Consequently, m-banking has emerged as an important e-banking channel, and considering its importance, a few countries have begun treating m-banking as a separate e-banking channel and not merely an extension of Internet banking (Lee and Chung, 2009; Shaikh and Karjaluoto, 2015). This recognition has led to the growth in the study of consumer perceptions of m-banking adoption and of the continuance usage performance actions taken by consumers living in both developed and developing countries. 


\section{"Insert Figure 1 about here"}

Although user acceptance or pre-adoption of m-banking services is a necessary condition for the effective implementation of m-banking technology (Tan et al., 2010; Teo et al., 2012), research has cited its continued usage (or post-adoption usage) as a pre-condition for its successful implementation (e.g., Zhou, 2012). Despite the huge market potential in the adoption and usage of m-banking services, little is known about the factors that influence the sustained use of mobile financial services after adoption (Kang et al., 2012). Consequently, marketing strategy research has long emphasised the need to investigate the m-banking continuous usage context (Chen, 2012). A broad analysis is necessary to identify the factors that determine users' continuous usage of m-banking services in two markets; nevertheless, a few studies have investigated the continuous usage of m-banking services in single-country contexts, including Taiwan (Chen, 2012), Korea (Gu et al., 2009; Kang et al., 2012; Kim et al., 2009), and India (Reji Kumar and Ravindran, 2012). These studies have provided limited understanding of the key factors driving consumers' continuous usage of m-banking services, an understanding that the current research aims to expand on by reporting a comparative study. A comparative study also has the potential to isolate important managerial implications of how m-banking services might be promoted more efficiently in different markets.

Given the practical relevance of the topic and the dearth of prior empirical work, this research aims to investigate continuous usage behaviour among consumers living in a mature market (Finland $[\mathrm{FI}]$ ) and an emerging market (South Africa $[\mathrm{ZA}]$ ). We examine three significant postadoption behavioural consequences - namely, trust, satisfaction, and word of mouth (WOM). 
Examination of these consequences in a dual-country assessment provides valuable insights into the dynamics of m-banking post-adoption consequences. By explaining users' intentions from their own perspectives (Luarn and Lin, 2005), this research can not only help m-banking authorities develop an m-banking system more accepted by users but also provide insight into the best way to promote new information systems to potential users.

This research uses qualitative data acquired by conducting in-depth semi-structured interviews with consumers who owned at least a cell phone, a smartphone, or a tablet and had used those devices to access m-banking services. The purpose of adopting a qualitative approach was to gain a deeper understanding of the post-adoption performance of a group of users of m-banking services.

In the next section, we provide a brief overview of m-banking and outline the theoretical framework of the study. Then, we present the research methodology and the results. Finally, we discuss the study's contributions to both theory and practice, outline its main limitations, and recommend avenues for future research.

\section{Theoretical background}

M-banking has received ample attention from the industry and policy makers in providing innovative banking services to demographically disbursed populations. Evidence (e.g., Jasperson et al., 2005; Shaikh and Karjaluoto, 2015; Venkatesh et al., 2008) strongly suggests that information systems, such as m-banking, are often under-utilised following implementation; users apply a narrow band of m-banking features and operate at low levels of feature use, while 
organisations under-utilise the functional potentials of the majority of the currently developed and installed information technology (IT) systems and applications. Consequently, understanding post-adoption consumer intention in information systems has emerged as an important issue in strategic marketing and information systems research in the past two decades.

\subsection{M-banking}

Research has suggested various definitions for m-banking that attempt to capture its scope, nature, and design. For example, Lee et al. (2014, p. 552) define m-banking as 'an extension of banking and financial services onto mobile networks and devices'. Other scholars have described it as an application of $\mathrm{m}$-commerce that enables customers to access banking information through mobile devices to conduct various transactions (e.g., Alafeef et al., 2012; Luo et al., 2010). In addition, research has described m-banking as an innovative communication channel in which the customer interacts with the bank via a mobile device, such as a mobile phone, personal digital assistant (PDA), or smartphone (Zhou, 2011). Smartphones are now considered a converged device that combines the functionalities of a PDA and a cell phone and thus have largely taken over PDAs. Against this backdrop, m-banking in this study refers to the use of cell phones, smartphones, and tablets to access personal bank accounts to manage banking affairs (e.g., checking account status) and various transactions (e.g., bill payments, investments). In the past, text message (SMS) banking was the dominant m-banking financial service technology (Shaikh and Karjaluoto, 2015; Zhou et al., 2010). Today, m-banking involves several other more sophisticated technologies, such as downloadable mobile applications and the use of a mobile browser. 
As Figure 2 shows, the m-banking user base is growing rapidly. In early 2013, Juniper Research predicted that more than 1 billion mobile phone users would embrace m-banking by the end of 2017, compared with just over 590 million that year.

"Insert Figure 2 about here"

A great amount of confusion surrounds the terms 'Internet' and 'mobile' banking. Although both are electronic banking delivery channels, Internet banking (also called 'net-banking' or 'online banking') is a channel for conducting transactions using a computer or a laptop (Karjaluoto et al., 2002; McKinsey \& Co. 2014; Pikkarainen et al., 2006) and normally requires a regular bank account. Conversely, m-banking refers to banking via mobile devices, including mobile phones, smartphones, and tablets, that give consumers direct access to their banking information for conducting various transactions, such as checking account status, transferring funds, paying bills, and making investments (Alafeef at el., 2012).

\subsection{M-banking in ZA and FI}

Mobile phone subscriptions have grown exponentially in Africa (e.g., Beger and Sinha, 2012; Crabbe et al., 2009; International Telecommunication Union, 2012). Beger and Sinha (2012) estimated that the number of mobile subscribers in Africa increased from 90 million in 2005 to more than 600 million in 2011, positioning Africa as 'the second largest mobile market in the world'. In ZA, four major banks dominate the banking industry (ABSA, FNB, Nedbank, and 
Standard Bank), each of which offers m-banking services (Shambare, 2011). Similarly, the payment of bills and bank transfers in ZA through mobile devices represents 54\% of monthly transactions on average, as opposed to $15.8 \%$ of transactions carried out at a bank branch and $11.4 \%$ at an automated teller machine (Shambare, 2011).

Finland, South Korea, and Japan are at the forefront of integrated mobile financial services (e.g., m-banking). M-banking services have been available in FI since 1996, and financial service firms other than banks can provide their services over mobile networks (Jyrkönen and Paunonen, 2003). The PC is still the most popular channel for processing banking transactions in FI, as $86 \%$ of bills are paid through online banking services (Statistics Finland, 2012). However, banking with mobile devices is growing and becoming more regular. The proportion of the overall adult population using m-banking is currently around $10 \%$ but has doubled in just one year. According to The Finnish Banker's Association (2013), m-banking is growing in popularity especially among younger people (18 to 28 years of age).

\subsection{Consequences of continuance usage behaviour of m-banking}

During the past decade, various studies (e.g., Chen, 2012; Chung and Kwon, 2009) have investigated several consequences that influence consumers' continuance intention to use mbanking services and other information systems. In this vein, Table 1 summarises major consequences of mobile information systems continuous usage. These consequences can be the most significant drivers for developing consumers' perceptions of mobile information systems continuous usage in developed and developing countries. 
"Insert Table 1 about here"

In a post-adoption scenario, an individual realises the full potential of information systems, such as m-banking, which then becomes an integral part of his or her work system (Chen, 2012). Despite the large market potential of the mobile commerce market and the recent technological advancements occurring within it, little information is available on the factors that can affect the sustained use of integrated mobile financial services after adoption (Kang et al., 2012). Therefore, bank management needs clarification on the consequences that affect consumer continuous usage of m-banking services rather than one-time adoption of these services.

Research on post-adoption behaviours has focused on continuance intention, defined as a user's intention to continue using a specific IT (Bhattacherjee, 2001a), and adopted it as a key dependent variable (Bhattacherjee, 2001a; Lin et al., 2005). Al-Debei et al. (2013) defined postadoption behaviour as behaviour pertaining to the usage of a particular information system after initial acceptance or adoption. They further argued that the decisions related to post-adoption behaviours are independent of those related to initial acceptance or adoption. Bhattacherjee (2001a), however, defined continuous intention as continued use of an information system by adopters, where a continuance decision (1) follows an initial acceptance decision, (2) is influenced by the usage experience, and (3) can potentially lead to ex post reversal of the initial decision. With regard to various adoption models in use, such as the Technology Acceptance Model, Unified Theory of Acceptance and Use of Technology, Information Systems Success Model, and Innovation Diffusion Theory, one of the most widely used conceptual models on 
information systems continuance intention (Bhattacherjee, 2001b) is the expectationconfirmation model (ECM). This model proposes that expectation-confirmation relationship affects post-adoption expectations (perceived usefulness) and satisfaction, which in turn affect continued information systems usage. Some authors (e.g., Thong et al., 2006), however, have used the extended ECM model and concluded that this model can provide supplementary information relevant to the understanding of continued IT usage.

\subsection{Trust, Satisfaction, and WOM}

Unlike existing research conducted on the usage of m-banking services, we examine trust and satisfaction as the main consequences of continuance usage behaviour. In addition, we assess one important outcome of trust and satisfaction—namely, WOM-as another consequence of mbanking continuous usage. Together, these three consequences are important outcomes of continuance usage behaviour in general (Bhattacherjee, 2001b; Lin and Wang, 2006). For example, Kim and Son (2009) noted that online services users' post-adoption behaviour includes four factors: usage intention, WOM, willingness to pay, and inattention to alternatives. Chea and Luo (2008) measured online consumers' post-adoption behaviour with three variables: continuance intention, recommendation, and complaint. Some of these variables have also been examined in the m-banking context (Chung and Kwon, 2009; Lee and Chung, 2009). However, the studies specifically addressing m-banking have mostly examined inexperienced consumers rather than continuance users (e.g., Hanafizadeh et al., 2014; Suoranta and Mattila, 2004). In addition, m-banking research has been silent on how WOM relates to the delivery channel or, in 
broader terms, to the bank. Nevertheless, trust has emerged as a property of relationships between two or more social actors.

Under relationship marketing theory, trust is identified as a key mediator that influences company actions on consumer behaviour (Koo and Wati, 2010). Trust has also been referred to as an individual belief that others will behave according to an individual's expectation (Grazioli and Jarvenpaa, 2000). In addition, the relationship between trust and intention has been widely confirmed (e.g., Kim and Prabhakar, 2004; Wang and Benbasat, 2005). Oliver (1997, p. 7) defines satisfaction as a pleasurable experience that arises from an actual experience in relation to the expected experience. In m-banking context, reliable and trustworthy m-banking services will increase the user satisfaction (Masrek et al., 2014). WOM involves the sharing of information about a product or a service between a consumer and a friend, colleague, or other acquaintance. Recently, WOM has attracted attention from information systems researchers (Zhou, 2011). WOM can influence a person's perception of a complex or difficult-to-assess service (Kim et al., 2009). Hennig-Thurau et al. (2004) described electronic WOM as occurring when online customers or potential customers seek information on products or companies and share their knowledge, experiences, and opinions, in both a positive and negative manner. The interrelationships among trust, satisfaction, and WOM are well-established. For example, using the ECM, Susanto et al. (2012) concluded that perceived security and satisfaction are strong determinants of consumers' decisions to re-use m-banking services. Chen (2012) stated that trust, along with satisfaction, has a positive effect on continuance intention (see also Lee, 2010). Chen (2012) analyzed the factors leading to the continuance intention to use blogs, 
Facebook, YouTube, Twitter, and iGoogle and found that electronic WOM played a significant role in creating satisfaction that ultimately produced continuance intention.

\section{Methodology}

As m-banking is a relatively new area of research (e.g., Cruz et al., 2010), we chose a qualitative approach using one-on-one, in-depth semi-structured interviews. In total, we conducted 36 interviews with experienced m-banking users, including professionals and students, in Jyväskylä and Johannesburg. Using a purposeful sampling technique, and in line with the study's purposes (Morse, 1991), we selected participants according to their m-banking experience (minimum six months). Thus, this sample contributes to the theoretical understanding of the subject of the study (Bryman and Bell, 2011, p. 500). In using interviews to provide its primary data, this research differs from most previous research in the field of m-banking. The qualitative data method chosen allows the respondents to structure their own accounts of the extended usage of mbanking services.

Patton (1987, p. 122) states that good questions in qualitative interviews should, at a minimum, be open-ended, neutral, sensitive and clear to the interviewees. Drawing on these criteria, we began our interview process with an open question, 'Why did you start to use m-banking services?' The interview protocol followed a semi-structured format that involves a series of questions. We pilot-tested the interview protocol on a small group of volunteers to identify the problems and refine them before collecting the data from a randomly selected sample. The usage 
of m-banking services among the samples varied from less than one year to more than four years. Table 1 provides the detailed distribution.

Considering the nature and importance of the study, we included responses only from those who had been using m-banking for at least for the six months before the study. This screening procedure ensured that the selected research participants had enough experience with m-banking services and were in the post-adoption rather than pre-adoption stage of their usage (Kang et al., 2012).

The purpose and objective of the study were explained to the participants, and all interviews were recorded and transcribed. Most of the interviews were completed within 20 to 30 minutes. Responses those were similar in nature, such as 'easy to use', 'easy/easiness', 'simple/simplicity', 'handy/handiness' and 'anytime/anywhere', were categorised under 'convenience/convenient'.

We read the transcripts several times before thematisation. To analyse the data, we followed a three-step process that incorporated data reduction, data display, and verification (Miles and Huberman, 1994, p. 10). In the first stage, we organised the transcriptions under the four themes. In the second phase, we analysed and tabulated each theme individually. Finally, we verified the data with all informants and three m-banking experts from large financial institutions, who received a summary of the themes derived from this study. This step helped us improve the credibility and reliability of the data collected. 


\subsection{Sample}

The sample was male dominated (64\%). More than $86 \%$ of the respondents were working professionals, while others were post-graduate students or self-employed. Just over half of those interviewed $(\mathrm{N}=19)$ were between ages 25 and 32; of the remainder, 13 were between ages 33 and 39, two were between ages 40 and 46, and two were over 50. Two-thirds of the respondents $(\mathrm{N}=24)$ had more than two years' experience with m-banking services, while only six had less than one year's experience. Against this background, we regarded the respondents as reliable informants with sufficient experience with m-banking services, through either smartphones or tablets. Table 2 presents the background information on the informants.

\footnotetext{
"Insert Table 2 about here"
}

Smartphones were the main portable device used by the majority of respondents $(\mathrm{N}=23)$ to access m-banking services, while only four respondents used tablets at the time. Nine respondents used a combination of the two to conduct their m-banking business. In addition, respondents used various data transmission technologies to access m-banking services; prominent among them was SMS (in ZA) and a mobile browser and applications provided by Finnish banks and downloaded onto portable devices.

\section{Results}


At the start of the interview, respondents were asked why they used m-banking services. This non-direct approach offered the informants an opportunity to talk about m-banking as a separate channel. According to our data, informants used m-banking services for essentially three major reasons: convenience, user friendliness, and immediate access to banking services. Other reasons for using m-banking included speed, accessibility, user interface, security, usefulness, and improved control of an account. The empirical analysis therefore offers strong evidence that $\mathrm{m}$ banking continuance usage behaviour primarily depends on the performance and usability of the technical service (e.g., SMS, mobile applications) supporting m-banking, a finding that is equally applicable in the mature and developing countries involved, because no significant difference existed between the responses in FI and ZA. As one informant explained:

When I sometimes need immediate access to my bank account, for instance to transfer money to my children's bank account or when I need to pay bills immediately but am not near my PC, then I can use the application on my mobile phone or tablet. I have been using this method for more than five years. (Mikko, male, FI)

Convenience was often highlighted as an important reason for using m-banking. As one respondent from SA stated:

By convenience I mean, when you wake up in the morning, you use your cell phone to make [a] payment to [a] third party anywhere in the world, you can get recharge airtime on your phone. So it is very convenient for me personally. (Nikita, female, ZA) 
Usage of m-banking services in both countries was also dependent on situational factors, such as visits to a bank branch, long queues, unfavorable weather (especially in FI), the law and order situation (especially in ZA), unanticipated needs, and immediate payments. Respondents perceived the availability of m-banking services as most advantageous in these situations.

\subsection{Trust}

Research has investigated the effect of trust on mobile user continuous usage in a variety of contexts, including mobile services (Zhou and Lu, 2011), m-banking (Gu et al., 2009), mobile shopping (Hung et al., 2012), and mobile payments (Zhou, 2013). The results indicate that trust has significant effects on post-adoption usage (e.g., Zhou, 2013; Zhou and Lu, 2011) and positively affects behavioural intention to use m-banking (e.g., Gu et al., 2009).

In line with these findings, the majority $(\mathrm{N}=33)$ of respondents also expressed trust in m-banking technology. Only a few $(\mathrm{N}=3)$ expressed reservations over the security and safety of the application and expected their banks to revisit the security parameters in m-banking technology, applications, and services to ensure efficiency.

Ifeel secure but there is a little doubt because it is a new thing and there is not much experience of this application, but it has not let me down yet. I have not been a victim of identity theft, but of course there is a little doubt. But I trust it. (Sami, male, SA) 
All the respondents who indicated trust stated that they trusted the application and their bank and had no qualms about continuing to use m-banking services in the near future. The factors that contributed to developing trust among users in both FI and ZA were quite similar. For example, our data indicated that the level of trust, in general, came from the lack of problems experienced to date with their m-banking services. Although some respondents did not totally trust mbanking, they still used it. Nevertheless, trust deficit and security fears about the m-banking applications were not uncommon among the respondents. Therefore, nurturing trust in mbanking services and enhancing the credibility of products should help the banking industry attract new customers, retain existing customers, and increase the volume of m-banking usage.

\subsection{Satisfaction}

Prior research has examined satisfaction in the context of the mobile context from the perspective of continuous usage of mobile instant messaging (Deng et al., 2010), mobile Internet services (Hong et al., 2006), mobile commerce (Lin and Shih, 2008), and mobile data services (Kim, 2012). There is broad agreement that satisfaction is an important variable explaining continuous usage. For example, Lin and Shih (2008) concluded that consumers might not use mobile commerce service without being totally satisfied with the system. Similarly, Zhou (2013) concluded that satisfaction, trust, and flow determine continuous intention to use mobile payments. Consequently, the results imply that service providers need to offer quality systems, information, and services to facilitate users' continuous usage of mobile payments. 
The study respondents expressed their satisfaction in different ways but, in general, were satisfied with the m-banking services offered by their respective banks. The discussion indicated that their level of satisfaction was largely due to the quality of the m-banking services offered by their banks, which were easy to use and had a good user interface:

I am very satisfied. It is simple and very easy to use. It has nothing useless, just the main points about my bank account. (Heini, female, FI)

I am very satisfied. On a scale of 1-5, I would choose 4. Because it works. It is easy to add beneficiaries and it is very secure. So I am happy about that. (Mike, male, ZA)

Nevertheless, one respondent expressed some dissatisfaction with the m-banking services he had used, finding the information supplied to be unnecessary. The respondent also explained his dissatisfaction with the type of information the bank provided:

My experience of using m-banking is quite annoying. It shows everything on my cell phone screen. Wherever I pay for anything, it comes immediately on my cell phone. It is so annoying. In the beginning it was so nice because it was showing the curves, graphs on my spending and also updates about the bills I was supposed to pay. (Jani, male, FI)

Approximately half the respondents $(\mathrm{N}=20)$ stated that they were 'very satisfied' and 'highly satisfied' with the mobile banking services. However, our observations revealed no significant difference in satisfaction of respondents living in FI and ZA. 


\section{$4.3 W O M$}

Although traditional (offline) WOM can play a major role in customers' buying decisions (Hennig-Thurau et al., 2004), our findings revealed that use of m-banking services did not affect respondents' ( $\mathrm{N}=22)$ willingness to spread positive WOM overall. Some respondents indicated that m-banking was not an appropriate subject to discuss with others:

I don't find it necessary to share my banking experience with my family or friends. I consider banking as [a] very personal matter not to be shared with others. (Joy, male, ZA)

No, I don't discuss this service. Maybe it is too common already. There is nothing new. I can 't... sell this to anyone by saying, "Hey, do you know this bank is offering m-banking?" (Antti, male, FI)

The data reveal that m-banking WOM is less prevalent in ZA than in FI, with nearly half the respondents in FI $(\mathrm{N}=8)$, compared with one-third $(\mathrm{N}=6)$ in $\mathrm{ZA}$, agreeing that they spread WOM after using m-banking services. However, when asked how frequently they spoke to friends and family about m-banking, the most common answer was 'not often'. In most cases, it is the convenience of using m-banking services that dominates the recommendation criteria:

A good example would be my domestic helper. She didn't have a bank account. So I first told her about m-banking and then opened an account for her. Now I transfer her salary from my cell 
phone to her account. She gets a notification immediately on her cell phone and she can go and draw her money. That's just how easy it is. (Saima, female, ZA)

Netherless, given the distinct characteristics of Internet and mobile communication channels, WOM deserves more attention from marketing researchers and professionals.

\section{Discussion}

M-banking is an emerging mobile commerce application that can offer an additional revenue source to both banks and telecom service providers (Kim et al., 2009). Building on the literature, we identified three important post-adoption consequences related to m-banking and discussed user perceptions of trust, satisfaction, and WOM in two countries. Table 3 presents the results and summarises the main outcomes of the study.

"Take in Table 3 about here"

Several prior studies have investigated the significant role of trust in the successful adoption of e-commerce and m-banking (Chung and Kwon, 2009; Kim et al., 2009; Lee and Chung, 2009; Lin, 2011). Trust remains a primary concern in the mobile e-commerce discipline in connection with issues such as m-banking, owing to its crucial role in mediating information exchange (Susanto et al., 2012). The findings of this study clearly show that users trust m-banking services. The factors contributing to the development of trust among users of m-banking in both FI and ZA were quite similar. Doubts about the credibility of m-banking applications reported by 
a few respondents have not deterred them from using m-banking. Rather, they wished to continue using m-banking services in the future. In line with the literature on m-banking (Kim et al., 2009), we confirm that trust plays a significant role in promoting continuous usage of mbanking services in different markets.

The major reason consumers decide to repurchase products or patronise services is their level of satisfaction (e.g., Hung et al., 2012; Pikkarainen et al., 2004; Zhou, 2013). The results show that the majority of the respondents were satisfied with their m-banking services. The respondents cited convenience, speed, user friendliness, and security as among the major factors increasing their level of satisfaction.

In most cases, the convenience of using m-banking services dominates the recommendation criteria. Existing theoretical perspectives suggest that WOM is driven by motivation (Berger and Schwartz, 2011) and conventional wisdom, which suggests that products need to be interesting to spur discussion (Berger and Schwartz, 2011). However, our research findings indicate that even in the presence of helpful m-banking services, respondents might not be interested in endorsing services to others. Some respondents emphasised that m-banking is too personal or, conversely, too common a subject to be discussed with other people.

\subsection{Managerial implications}

M-banking is a rapidly emerging banking delivery channel, and prior research (Shih et al., 2010, p. 258) has deemed it "a highly challenging task" for banks to encourage customers to continue 
using m-banking services and attract new customers to the service. Our research contributes in several important ways to help banks understand the m-banking consumer and unlock the vast potential of m-banking services. First, the results show that smartphones have established themselves as the key engagement platform and are the mobile devices most frequently used to access m-banking services. Although the tablet was not as commonly used as the smartphone to access bank accounts, it is gradually becoming a mainstream device in both markets. Thus, we would encourage banks and service providers to develop their marketing and m-banking strategies and associated applications for these two dominant devices to gain competitive advantage. Marketing strategies should be targeted at both existing and potential customers. Similarly, user-friendly processes for downloading and authenticating m-applications would help drive usage and attract new consumers.

Second, the four consequences examined are relevant to marketers wanting to extend usage of m-banking among their target audience. This research helps clarify the reasons behind mbanking continuance usage. For example, while convenience and user friendliness were the primary reasons cited by the majority of participants, trust deficit and security fears in the applications and procedures behind m-banking services remained key barriers to m-banking growth and usage. The findings indicate that the level of trust stems from whether users have experienced any problems with their m-banking services. In the wake of growing security breaches, we suggest that banks build awareness and educate customers on existing security features and forms of protection. 
Although the study findings cannot offer definite conclusions on the effects of WOM on continuous usage of m-banking services, it seems logical that given the explosive growth of social media, banks should treat this type of communication as an opportunity. As consumers become increasingly overwhelmed by product and service choices, positive WOM could help stimulate the buying and usage decision-making process.

This study offers managers some insight into how m-banking post-adoption behaviour differs in a mature and an emerging market context. We found no significant differences in the underlying reasons for the use of m-banking services in the two contexts, though the technology in use differs to some extent. The major differences between the two national contexts include users' commitment to their m-banking service providers and their willingness to provide positive WOM. We also found that m-banking users in FI were more willing to promote the service among their social networks than their counterparts in ZA, even those who were satisfied with the services received.

\subsection{Limitations and future research directions}

This study has several limitations that provide opportunities for future research. First, we examined m-banking users in two countries and used a qualitative method. Thus, our findings cannot be widely generalised, and cause-and-effect relationships could not be established.

Second, the consequences of continuous m-banking usage identified are not exhaustive, and thus future research should consider additional outcomes of m-banking continuous usage, such as self-image, engagement, and value-in-use. Third, the respondents were mainly working 
professionals, with the sample including only a small percentage of other types of people. Ideally, future research would include informants from a variety of backgrounds and a range of occupations and examine other markets as well. Finally, we encourage researchers to test the four consequences of continuous usage behaviour identified here and gauge their relative importance with a survey study.

Taking into account the limitations, scope, and nature of this study, we contend that perception and usage of m-banking services are considerably influenced by local custom, market conditions, and regulations. As a result, research findings may vary from one country to another and from one region to another. Usage patterns may vary significantly between countries, depending on cultural differences and market conditions (Snellman, 2006). Accordingly, we strongly recommend that more comparative studies be undertaken. 


\section{References}

Adesina, A.A. and Ayo, C.K. (2010) 'An empirical investigation of the level of users' acceptance of e-banking in Nigeria', Journal of Internet Banking \& Commerce, Vol. 15, No. 1, pp.1-13.

Akturan, U. and Tezcan, N. (2012) 'Mobile banking adoption of the youth market: perceptions and intentions', Marketing Intelligence \& Planning, Vol. 30, No. 4, pp.444-459.

Alafeef, M., Singh, D. and Ahmad, K. (2012) 'The influence of demographic factors and user interface on mobile banking adoption: a review', Journal of Applied Sciences, Vol. 12, No. 20, pp.2082-2095.

Al-Debei, M.M., Al-Lozi, E. and Papazafeiropoulou, A. (2013) 'Why people keep coming back to Facebook: explaining and predicting continuance participation from an extended theory of planned behavior perspective', Decision Support Systems, Vol. 55, No. 1, pp.43-54.

CISCO (2014) Mobile money service, http://www.cisco.com/c/en/us/solutions/collateral/serviceprovider/vni-service-adoption-forecast/Cisco_Safaricom_CS.pdf. (Accessed December 10, 2014). 
Beger, G. and Sinha, A. (2012) 'South African mobile generation: Study on South African young people on mobiles', http://www.unicef.org/southafrica / SAF_resources_mobilegeneration.pdf. (Accessed 1 April, 2014).

Berger, J.A. and Schwartz, E.M. (2011) 'What drivers immediate and on-going word-ofmouth?', Journal of Marketing Research, Vol. 48, No. 5, pp.869-880.

Bhattacherjee, A. (2001a) 'An empirical analysis of the antecedents of electronic commerce service continuance', Decision Support Systems, Vol. 32, No. 2, pp.201-214.

Bhattacherjee, A. (2001b) 'Understanding information systems continuance: an expectationconfirmation model', MIS Quarterly, Vol. 25, No. 3, pp.351-370.

Bryman, A. and Bell, E. (2011) Business Research Methods, 3rd ed., Oxford University Press, Oxford, UK.

Chea, S. and Luo, M.M., (2008) 'Post-adoption behaviours of e-service customers: the interplay of cognition and emotion', International Journal of Electronic Commerce, Vol. 12, No. 3, pp.29-56.

Chen, S. (2012) 'To use or not to use: understanding the factors affecting continuance intention of mobile banking', International Journal of Mobile Communications, Vol. 10, No. 5, pp.490507. 
Choi, H., Kim, Y. and Kim, J. (2011) 'Driving factors of post adoption behavior in mobile data services', Journal of Business Research, Vol. 64, No. 11, pp.1212-1217.

Chung, N. and Kwon, S. J. (2009) 'Effect of trust level on mobile banking satisfaction: a multigroup analysis of information system success instruments', Behaviour \& Information Technology, Vol. 28, No. 6, pp.549-562.

Chung, N., and Kwon, S. J. (2009) 'The effects of customers' mobile experience and technical support on the intention to use mobile banking', CyberPsychology \& Behavior, Vol 12, No. 5, $539-543$.

Crabbe, M., Standing, C., Standing, S. and Karjaluoto, H. (2009) 'An adoption model for mobile banking in Ghana', International Journal of Mobile Communications, Vol. 7, No. 5, pp.515-543.

Cruz, P., Neto, L.B.F., Muñoz-Gallego, P. and Laukkanen, T. (2010) 'Mobile banking rollout in emerging markets: evidence from Brazil', International Journal of Bank Marketing, Vol. 28, No. 5, pp.342-371.

Deng, Z., Lu, Y., Wei, K.K. and Zhang, J. (2010) 'Understanding customer satisfaction and loyalty: an empirical study of mobile instant messages in China', International Journal of Information Management, Vol. 30, No. 4, pp.289-300. 
Ensor, B., Montez, T. and Wannemacher, P. (2012) 'The state of mobile banking 2012'.

Forrester Research, http://www.miteksystems.com/files/mitek/docs/the_state_of_ mobile_banki.pdf (Accessed 15 April, 2014).

The Finnish Banker's Association (2013) 'Säästäminen, luotonkäyttö ja maksutavat', http://www.fkl.fi/materiaalipankki/julkaisut/Julkaisut/Saastaminen_luotonkaytto _ja_maksutavat_2013.pdf (Accessed 1 April, 2014).

Grazioli, S. and Jarvenpaa, S.L. (2000) 'Perils of internet fraud: An empirical investigation of deception and trust with experienced internet consumers', IEEE Transactions on Systems, Man, and Cybernetics Part A: Systems and Humans, Vol. 30, No. 4, pp.395-410.

Gu, J., Lee, S. and Suh, Y. (2009) 'Determinants of behavioral intention to mobile banking', Expert Systems with Applications, Vol. 36, No. 9, pp.11605-11616.

Hanafizadeh, P., Behboudi, M., Koshksaray, A.A. and Tabar, M.J.S. (2014) 'Mobile-banking adoption by Iranian bank clients', Telematics and Informatics, Vol. 31, No. 1, pp.62-78.

Hennig-Thurau, T., Gwinner, K.P., Walsh, G. and Gremler, D.D. (2004) 'Electronic word-ofmouth via consumer-opinion platforms: what motivates consumers to articulate themselves on the Internet', Journal of Interactive Marketing, Vol. 18, No. 1, pp.38-52. 
Hong, S, Thong, J.Y.L. and Tam, K.Y. (2006) 'Understanding continued information technology usage behavior: a comparison of three models in the context of mobile internet', Decision Support Systems, Vol. 42, No. 3, pp.1819-1834.

Hung, M.C., Hwang, H.G. and Hsieh, T.C. (2007) 'An exploratory study on the continuance of mobile commerce: an extended expectation-confirmation model of information system use', International Journal of Mobile Communications, Vol. 5, No. 4, pp.409-422.

Hung, M.C., Yang, S.T. and Hsieh, T.C. (2012) 'An examination of the determinants of mobile shopping continuance', International Journal of Electronic Business Management, Vol. 10, No. 1, pp.29-37.

International Telecommunication Union (2012) 'Trends in telecommunications report: Smart regulation for broadband world', http://www.itu.int/dms_pub/itu-d/opb/reg/D-REG-TTR.132012-SUM-PDF-E.pdf. (Accessed 1 April, 2014).

Jasperson, J.S., Carter, P.E. and Zmud, R. W. (2005) 'A comprehensive conceptualization of post-adoptive behaviors associated with information technology enabled work systems', MIS Quarterly, Vol. 29, No.3, pp.525-557.

Juniper Research (2013) 'Mobile banking: handset \& tablet market strategies 2013-2017', http://www.juniperresearch.com/viewpressrelease.php?pr=356 (Accessed 1 April, 2014). 
Jyrkönen H. and Paunonen H., (2003) 'Card, Internet and mobile payments in Finland', Bank of Finland, Discussion Paper, No. 8/2003.

Kang, H., Lee, M.J. and Lee, J. K. (2012) 'Are you still with us? A study of the post-adoption determinants of sustained use of mobile-banking services', Journal of Organizational Computing and Electronic Commerce, Vol. 22, No. 2, pp.132-159.

Karjaluoto, H., Jarvenpaa, L. and Kauppi, V. (2009) 'Antecedents of online banking satisfaction and loyalty: empirical evidence from Finland', International Journal of Electronic Finance, Vol. 3, No. 3, pp.253-269.

Karjaluoto, H., Mattila, M. and Pento, T. (2002) 'Factors underlying attitude formation towards online banking in Finland', International Journal of Bank Marketing, Vol. 20, No. 6, pp.261272.

Kim, B. (2012) 'The diffusion of mobile data services and applications: exploring the role of habit and its antecedents', Telecommunications Policy, Vol. 36, No. 1, pp.69-81.

Kim, G., Shin, B. and Lee, H.G. (2009) 'Understanding dynamics between initial trust and usage intentions of mobile banking', Information Systems Journal, Vol. 19, No. 3, pp.283-311.

Kim, K. and Prabhakar, B. (2004) 'Initial trust and the adoption of B2C e-commerce: the case of internet banking', Database for Advances in Information System, Vol. 35, No. 2, pp.50-64. 
Kim, S.S. and Son, J.-Y. (2009) 'Out of dedication or constraint? A dual model of post-adoption phenomena and its empirical test in the context of online services', MIS Quarterly, Vol. 33, No. 1, pp.49-70.

Klein, M. and Mayer, C. (2011) 'Mobile banking and financial inclusion', World Bank, https://openknowledge.worldbank.org/handle/10986/3427 (Accessed 1 April, 2014).

Koo, C. and Wati, Y. (2010) 'Toward an understanding of the mediating role of trust in mobile banking service: an empirical test of Indonesia case', Journal of Universal Computer Science, Vol. 16, No. 13, pp.1801-1824.

Lee, K.C. and Chung, N. (2009) 'Understanding factors affecting trust in and satisfaction with mobile banking in Korea: a modified DeLone and McLean's model perspective', Interacting with Computers, Vol. 21, No. 5, pp.385-392.

Lee, M.C. (2010) 'Explaining and predicting users' continuance intention toward e-learning: an extension of the expectation-confirmation model', Computers \& Education, Vol. 54, No. 2, pp.506-516.

Lee, H., Harindranath, G., Oh, S., and Kim, D. J. (2014) 'Provision of mobile banking services from an actor-network perspective: Implications for convergence and standardization', Technological Forecasting and Social Change, Vol. 90, pp.551-561. 
Liang, T.P. and Yeh, Y.H. (2011) 'Effect of use contexts on the continuous use of mobile services: the case of mobile games', Personal and Ubiquitous Computing, Vol. 15, No. 2, pp.187-196.

Liao, C.H., Tsou, C.W. and Huang, M.F. (2007) 'Factors influencing the usage of 3G mobile services in Taiwan', Online Information Review, Vol. 31, No. 6, pp.759-774.

Lin, C.S., Wu, S. and Tsai, R.J. (2005) 'Integrating perceived playfulness into expectationconfirmation model for Web portal context', Information \& Management, Vol. 42, No. 5, pp.683-693.

Lin, H. (2011) 'An empirical investigation of mobile banking adoption: the effect of innovation attributes and knowledge-based trust', International Journal of Information Management, Vol. 31, No. 3, pp.252-260.

Lin, H. and Wang, Y. (2006) 'An examination of the determinants of customer loyalty in mobile commerce contexts', Information \& Management, Vol. 43, No. 3, pp.271-282.

Lin, Y.M. and Shih, D.H. (2008) 'Deconstructing mobile commerce service with continuance intention', International Journal of Mobile Communications, Vol. 6, No.1, pp.67-87. 
Lu, H. P. and Su, P. Y. J. (2009) 'Factors affecting purchase intention on mobile shopping web sites', Internet Research, Vol. 19, No. 4, pp.442-458.

Luarn, P. and Lin, H. H. (2005) 'Toward an understanding of the behavioral intention to use mobile banking', Computers in Human Behavior, Vol. 21, No. 6, pp.873-891.

Luo, X., Li, H., Zhang, J. and Shim, J.P. (2010) ‘Examining multi-dimensional trust and multifaceted risk in initial acceptance of emerging technologies: an empirical study of mobile banking services', Decision Support Systems, Vol. 49, No. 2, pp.222-234.

McKinsey \& Co. (2014) 'The rise of the digital bank', McKinsey \& Co article, July, http://www.mckinsey.com/insights/business_technology/the_rise_of_the_digital_bank, (accessed 1 December 2014).

Miles, M.B. and Huberman, A.M. (1994) Qualitative Data Analysis, $2^{\text {nd }}$ ed., Sage Publications, Thousand Oaks, CA.

Morse J.M. (1991) ‘Strategies for sampling’, In J.M. Morse (Ed.), Qualitative Nursing Research: A Contemporary Dialogue, Sage, Newbury Park, CA, pp.127-145.

Ng, E.H. and Kwahk, K.Y. (2010) 'Examining the determinants of mobile internet service continuance: a customer relationship development perspective', International Journal of Mobile Communications, Vol. 8, No. 2, pp.210-229. 
Oliver, R.L. (1997) Satisfaction. A Behavioral Perspective on the Consumer, McGraw-Hill, New York.

Patton, M.Q. (1987) How to Use Qualitative Methods in Evaluation, Sage, London, UK.

Pikkarainen, T., Pikkarainen, K., Karjaluoto, H. and Pahnila, S. (2004) 'Consumer acceptance of online banking: an extension of the technology acceptance model', Internet Research, Vol. 14, No. 3, pp.224-235.

Pikkarainen, K., Pikkarainen, T., Karjaluoto, H. and Pahnila, S. (2006) 'The measurement of end-user computing satisfaction of online banking services: empirical evidence from Finland', International Journal of Bank Marketing, Vol. 24, No. 3, pp.158-172.

Ratten, V. (2012) 'Entrepreneurship, e-finance and mobile banking', International Journal of Electronic Finance, Vol. 6, No. 1, pp.1-12.

Reji Kumar, G. and Ravindran, D. S. (2012) 'An empirical study on service quality perceptions and continuance intention in mobile banking context in India', Journal of Internet Banking \& Commerce, Vol. 17, No. 1, pp.1-22. 
Schierz, P.G., Schilke, O. and Wirtz, B.W. (2010) 'Understanding consumer acceptance of mobile payment services: an empirical analysis', Electronic Commerce Research and Applications, Vol. 9, No. 3, pp.209-216.

Shaikh, A.A. and Karjaluoto, H. (2015) 'Mobile banking adoption: a literature review', Telematics and Informatics, Vol. 32, No. 1, pp.129-142.

Shambare, R. (2011) 'Cell phone banking adoption in South Africa', Business and Economic Research, Vol. 1, No. 1, pp.1-15.

Shih, K., Hung, H. and Lin, B. (2010) 'Assessing user experiences and usage intentions of mbanking service', International Journal of Mobile Communications, Vol. 8, No. 3, pp.257-277.

Snellman, K., (2006) 'Mobile services market in Finland 2005', http://www.lvm.fi/pressreleases/820232/study-of-the-mobile-services-markets-in-2005-packageoffers-brought-increased-text-message-traffic (Accessed 1 April, 2014).

Statistics Finland (2012) 'Two-thirds of Finns are online shoppers', http://www.stat.fi/til/sutivi/2012/sutivi_2012_2012-11-07_tie_001_en.html (Accessed 1 April, 2014).

Suoranta, M. and Mattila, M. (2004) 'Mobile banking and consumer behaviour: new insights into the diffusion pattern', Journal of Financial Services Marketing, Vol. 8, No. 4, pp.354-366. 
Susanto, A., Chang, Y., Zo, H. and Park, M.C. (2012) 'The role of trust and security in Smartphone banking continuance'. Proceedings of the IEEE International Conference on Systems, Man, and Cybernetics, Korea, Seoul.

Tan, K.S., Chong, S.C., Loh, P.L. and Lin, B. (2010) 'An evaluation of e-banking and m-banking adoption factors and preference in Malaysia: a case study', International Journal of Mobile Communications, Vol. 8, No. 5, pp.507-527.

Teo, A., Tan, G.W., Cheah, C., Ooi, K. and Yew, K. (2012) 'Can the demographic and subjective norms influence the adoption of mobile banking?', International Journal of Mobile Communications, Vol. 10, No. 6, pp.578-597.

Thong, J.Y.L., Hong, S. and Tam, K.Y. (2006) 'The effects of post-adoption beliefs on the expectation-confirmation model for information technology continuance', International Journal of Human-Computer Studies, Vol. 64, No. 9, pp.799-810.

Tojib, D. and Tsarenko, Y. (2012) 'Post-adoption modeling of advanced mobile service use', Journal of Business Research, Vol. 65, No. 7, pp.922-928.

Venkatesh, V., Brown, S.A., Maruping, L.M., and Bala, H. (2008) 'Predicting different conceptualizations of system use: the competing roles of behavioral intention, facilitating conditions, and behavioral expectation', MIS Quarterly, Vol. 32, No. 3, pp.483-502. 
Wang, W. and Benbasat, I. (2005) 'Trust in and adoption of online recommendation agents', Journal of the Association for Information Systems, Vol. 6, No. 3, pp.72-101.

Zhao, L., Lu, Y., Zhang, L. and Chau, P.Y. (2012) 'Assessing the effects of service quality and justice on customer satisfaction and the continuance intention of mobile value-added services: an empirical test of a multidimensional model', Decision Support Systems, Vol. 52, No. 3, pp.645656.

Zhou, T. (2011) 'An empirical examination of users' post-adoption behaviour of mobile services', Behaviour \& Information Technology, Vol. 30, No. 2, pp.241-250.

Zhou, T. (2012) 'Understanding users' initial trust in mobile banking: an elaboration likelihood perspective', Computers in Human Behavior, Vol. 28, No. 4, pp.1518-1525.

Zhou, T. (2013) 'An empirical examination of continuance intention of mobile payment services', Decision Support Systems, Vol. 54, No. 2, pp.1085-1091.

Zhou, T. and Lu, Y. (2011) 'Examining postadoption usage of mobile services from a dual perspective of enablers and inhibitors', International Journal of Human-Computer Interaction, Vol. 27, No. 12, pp.1177-1191. 
Zhou, T., Lu, Y. and Wang, B. (2010) 'Integrating TTF and UTAUT to explain mobile banking user adoption', Computers in Human Behavior, Vol. 26, No. 4, pp.760-767. 


\section{List of Figures}

Figure 1 M-banking as a sub-set of e-finance

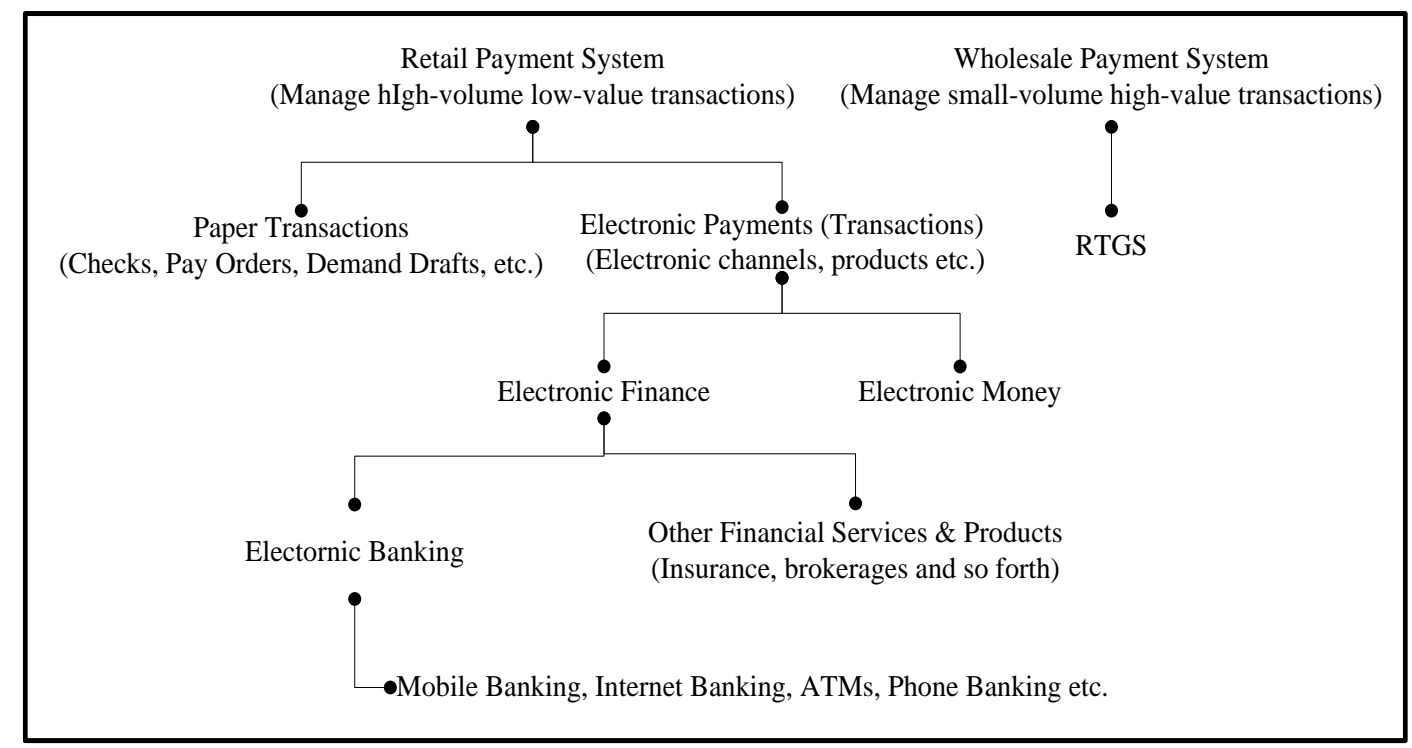


Figure 2. Growth of m-banking

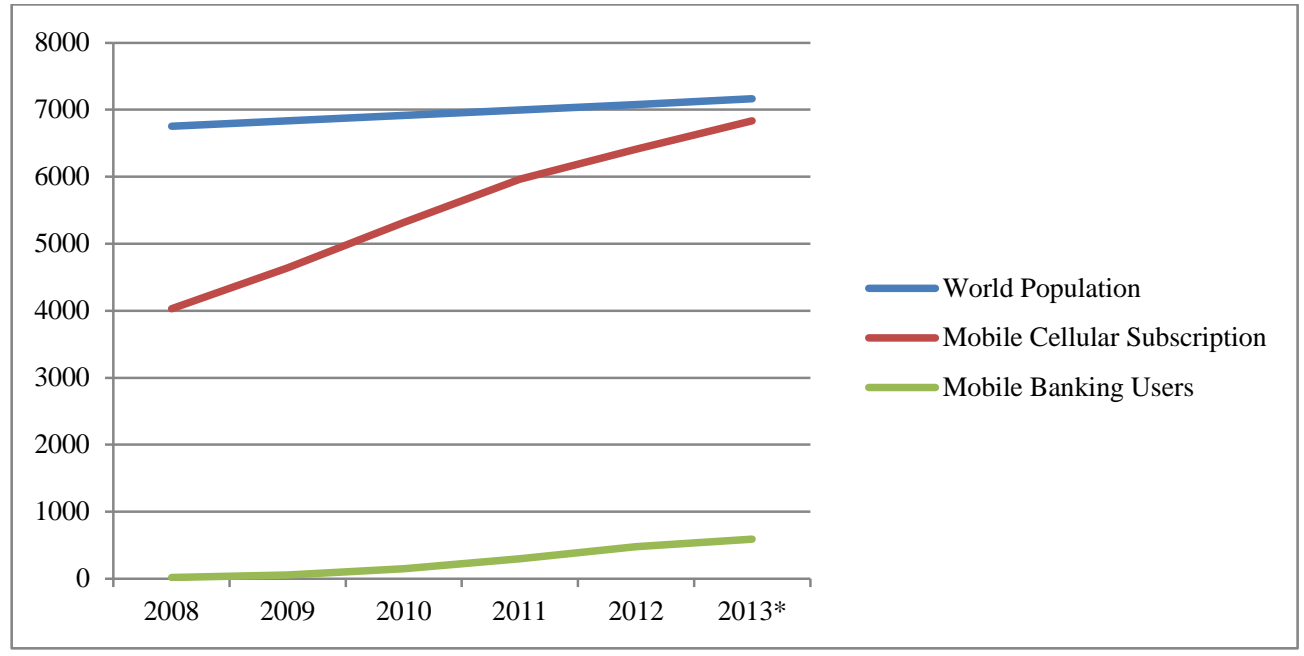

Source: International Telecommunication Union (2012); Juniper Research (2013). 


\section{List of Tables}

Table 1 Research on the continuous usage of mobile information systems

\begin{tabular}{|c|c|c|c|c|}
\hline Studies & IS & Meth./Country (VR) & IS Theory/Model & Significant Consequences \\
\hline \multicolumn{5}{|l|}{ (2012) } \\
\hline Zhao et al. (2012) & MS & Survey/China (1075) & SDM & TSAT;CSAT;IQ;IJ \\
\hline Zhou (2013) & MPS & Survey/China (195) & SDM & TRU;SAT;FLO \\
\hline Gu et al. (2009) & $\mathrm{MB}$ & Survey/Korea $(910)$ & TAM+ & PU;PEOU;TRU \\
\hline Karjaluoto et al. (2009) & OLB & Survey/FI (183) & E-S-QUAL & SAT; PU; PEOU \\
\hline Choi et al. (2011) & MDS & Survey/Korea (997) & SDM & $\mathrm{PV} ; \mathrm{PC} ; \mathrm{SI}$ \\
\hline $\operatorname{Kim}(2012)$ & MDS & Survey/Korea (317) & SDM & HAB;SAT;PU;CONF;ENJ \\
\hline Hung et al. (2012) & MShop & Survey/Taiwan (244) & ECM+ & PU;SAT;TRU;CONF \\
\hline $\mathrm{Lu}$ and $\mathrm{Su}(2009)$ & MShop & Survey/Taiwan (369) & TAM+ & PU;PEOU;ANX;ENJ \\
\hline Hung et al. (2007) & $\mathrm{MC}$ & Survey/Taiwan (891) & ECM+ & PU;SAT;CONF;PI \\
\hline Deng et al. (2010) & MIM & Survey/China (541) & SDM & LOY;SAT;SC;TRU \\
\hline
\end{tabular}

$V R=$ Valid Responses $;+=$ Extended $; I S=$ information systems; $M S=$ mobile services; $M P S=$ mobile payment services;

$M B=$ mobile banking; $M D S=$ mobile data services; $M$ Shop=mobile shopping; $M C=$ mobile commerce; $M I S=$ mobile internet services; $M G=$ mobile games; $M I M=$ mobile instant messages; $O L B=$ online banking; $S D M=$ self-developed model; 
ECM=expectation-confirmation model; $E D T=$ expectation disconfirmation theory; $E C M-I T=$ expectation-confirmation model in IT domain; TAM= technology acceptance model; $S Q B=$ status quo bias; TRA=theory of reasoned action; PU=perceived usefulness; PEOU=perceived ease of use; TRU=trust; SAT=satisfaction; TSAT=transaction-specific satisfaction; $C S A T=$ cumulative satisfaction $P V=$ perceived value; $P R V=$ personal values; $P C=$ perceived cost; $C O N F=$ confirmation; $D C O N F=$ dis-confirmation; $S I=$ social influence $; F L O=$ flow; $S B=$ switching barrier; $S C=$ switching cost; PI=personal innovativeness; $F A M=$ familiarity; $E V=$ experiential value; $E N J=$ enjoyment; $A T T=$ attitude; $P L A Y=$ playfulness; $S N=$ subjective norms; $P M V=$ perceived monetary value; HAB=habit; $A N X=$ anxiety; $C O M P=$ compatibility; $L O Y=$ loyalty; $P E R=$ performance; $I Q=$ interaction quality; $I J=$ interactional justice; $R Q=$ relationship quality; $S Q=$ service quality; $P R=$ perceived risk;

$T R=$ technology readiness; $C P=$ channel preference 
Table 2 Profile of the Informants

\begin{tabular}{|c|c|c|c|c|c|c|}
\hline & FI $(\mathrm{N})$ & $\%$ & $\mathrm{ZA}(\mathrm{N})$ & $\%$ & Total $(\mathrm{N})$ & $\%$ \\
\hline \multicolumn{7}{|l|}{ Gender } \\
\hline Female & 8 & 44.4 & 5 & 27.8 & 13 & 36.1 \\
\hline Male & 10 & 55.6 & 13 & 72.2 & 23 & 63.9 \\
\hline \multicolumn{7}{|l|}{ Age } \\
\hline $25-32$ & 10 & 55.6 & 9 & 50.0 & 19 & 52.8 \\
\hline $33-39$ & 5 & 27.8 & 8 & 44.4 & 13 & 36.1 \\
\hline $40-49$ & 2 & 11.1 & - & - & 2 & 5.6 \\
\hline$>50$ & 1 & 5.6 & 1 & 5.6 & 2 & 5.6 \\
\hline \multicolumn{7}{|l|}{ Occupation } \\
\hline Working professional & 16 & 88.9 & 15 & 83.3 & 31 & 86.1 \\
\hline Student & 2 & 11.1 & 2 & 11.1 & 4 & 11.1 \\
\hline Self-employed & - & - & 1 & 5.6 & 1 & 2.8 \\
\hline \multicolumn{7}{|l|}{ Type of device } \\
\hline Smartphone & 9 & 50.0 & 14 & 77.8 & 23 & 63.9 \\
\hline Tablet & 2 & 11.1 & 2 & 11.1 & 4 & 11.1 \\
\hline Both & 7 & 38.9 & 2 & 11.1 & 9 & 25.0 \\
\hline \multicolumn{7}{|l|}{ Usage history } \\
\hline$<1$ year & 3 & 16.7 & 3 & 16.7 & 6 & 16.7 \\
\hline $1-2$ years & 7 & 38.9 & 8 & 44.4 & 15 & 41.7 \\
\hline $2-3$ years & 2 & 11.1 & 4 & 22.2 & 6 & 16.7 \\
\hline 4 years or more & 6 & 33.3 & 3 & 16.7 & 9 & 25.0 \\
\hline
\end{tabular}


Table 3 Summary of study findings

\begin{tabular}{|c|c|c|}
\hline M-banking Usage $(\mathrm{N}=36)$ & Major Study Outcomes & Major Marketing \& Organisational Outcomes \\
\hline $\begin{array}{l}\text { Major m-banking usage drivers } \\
\text { - Immediate access to bank account / financial } \\
\text { information } \\
\text { - User friendliness of application and interface } \\
\text { - Convenience of use anytime, anywhere } \\
\text { - Speed } \\
\text { - Accessibility } \\
\text { - Usefulness (e.g., improved control of an } \\
\text { account) }\end{array}$ & $\begin{array}{l}\text { Trust } \\
\text { - Bank's reputation is reflected in trust in m-banking application. } \\
\text { - Trust deficit and security fears about m-banking applications and } \\
\text { services were not uncommon among the users. } \\
\text { Satisfaction } \\
\text { - Most respondents were satisfied with m-banking. } \\
\text { - M-banking satisfaction is reflected in satisfaction with the bank. } \\
\text { - Convenience, user friendliness, and speed emerged as main sub- } \\
\text { topics related to satisfaction. } \\
\text { WOM } \\
\text { - The respondents generally believe that m-banking is not an } \\
\text { appropriate subject to discuss with others. However, a few have } \\
\text { spread positive WOM on m-banking among their family and friends. }\end{array}$ & $\begin{array}{l}\text { - M-banking is a rapidly emerging banking delivery channel. } \\
\text { - Smartphones have established themselves as the key } \\
\text { frequently used to access m-banking services. } \\
\text { - There is no significant difference in the underlying reasons } \\
\text { for the use of m-banking services in an emerging market } \\
\text { and mature market, though the technology in use differs to } \\
\text { some extent. The major differences between the two } \\
\text { national contexts include users' commitment to their m- } \\
\text { banking service providers and their willingness to provide } \\
\text { positive WOM. } \\
\text { - M-banking services should be a vital part of a bank's } \\
\text { strategy to retain current customers. }\end{array}$ \\
\hline
\end{tabular}


